\title{
Investigating the Causes of the Current Labor Shortage in Romania
}

\author{
Manea Ludmila Daniela \\ manealudmiladaniela@gmail.com \\ Virlanuta Florina Oana \\ florinaoana27@yahoo.com \\ Muntean Mihaela Carmen \\ mihaela c muntean@yahoo.com \\ Dunarea de Jos University of Galati, Romania
}

\begin{abstract}
In the evolution of human society, the labour force has been the main component of the means of production. Without this element, the economic and social life would not even exist today, related to the level of development attained. Human capital, or highly qualified workforce, is an essential resource. Developed countries faced with an excess of demand for skilled workers that cannot be covered by the internal labor force formed in the national education system. As a result, developing countries become extremely competitive in attracting highly qualified workforce to bridge this gap. Unfavorable demographic trends, lack of skills and persistence of high unemployment have contributed to the reconsideration of restrictive policies on international labor migration. In this respect, we intend to analyse in this article the causes of the current shortage on the Romanian labour market. Thus, we will address the demographic, educational and migratory phenomena, identifying the impact of these factors on the socio-economic environment.
\end{abstract}

Keywords: labour shortage, demographic aging, migration, education, human capital, Romania

Jel code: J11, J21, J24

\section{Introduction}

The labour force is the active and key factor of economic activity, while the means of production, including the most advanced ones, represent the inert factor, an accumulation of past work. Without the direct or indirect intervention of the labour force, production and other economic activities cannot take place and the resources available to mankind cannot be capitalized.

B. Gazier (1991) defines human capital as "the whole of the productive capacities of an individual (or of a group of individuals), encompassing his or her active skills in the broadest sense of the word: general or specific knowledge, ability, skills, experience". He rightly believes that each individual has bot an innate and an acquired ability, aspect which is also emphasized by the theory of human capital.

The impact of the Industrial Revolution on society has been enormous, fundamentally changing the way of life and the perception of work. Today we are going through a major change in the economy and, implicitly, of society: the transition from the industrial economy to a service economy [3].

Among the changing features of the world of work in Europe has been the greater diversity of employment relations, notably the rise in part-time, temporary and self-employment. [6] In spite of all the existing strategies in the field of labor force, we can say that is a national crisis on the labor market, generated mainly by the following factors:

- migration

- changing employers' requirements regarding employee competencies

- the difficulties of the education system to adapt to the current needs of the labor market

- aging population 
Below, we shall analyse the causes of the labour shortage at a national level, by taking into account the implications of the aging population, the migration phenomenon and the challenges to which the education system should adapt.

\section{Literature review}

An important modern economic theory of work, employment and productivity is the theory of human capital and of the consumer, and those who have taken the first steps in this direction are: Gary Becker, Theodor Schultz, Milton Friedman and other professors at the University of Chicago.

The term human capital belongs to T. Schultz, who developed his concept by saying that all human abilities are either innate or acquired, the attributes that have value and that can be augmented by proper investment forming the human capital. But the idea of investing in human capital belongs to Adam Smith, who advocated in "The Nation's Wealth" that differences between the methods of individuals with different levels of education and professional training reflect the differences in the efficiency needed to cover the costs of acquiring those professional skills.

For the worker, the expected gains from investing in human capital are: higher income levels, more professional satisfaction, better career prospects and, at a certain time, but to a lesser extent today, the belief that he has a secure job. The decision to acquire professional skills is a decision to invest.

Among all economists, Gary Becker stands out due to his two studies "Human Capital" and "Human Behaviour: An Economic Approach". According to his theory, G. Becker believes that investing in education and individual training is the same as investing in equipment.

The economic effects of investment in education on the chances of getting employed and on income justify such an investment. The approach of human capital also allows the estimation of the high-school and higher education costs, as well as the profits obtained from it.[1]

Investment in human capital include schooling, workplace training, healthcare, migration, and searching for price and income information.

There is a close connection between the human capital and economic development. The systematic application of scientific knowledge to the production of goods has enormously increased the value of education and of schooling at the workplace. Many countries that succeeded in permanently increasing the income have also had great increases in education and the training of the labour force. Education and schooling are helpful in keeping up with the technological change and the advanced productivity in the production and service sectors.

G. Becker's general theory on human capital has a number of very important applications, helping to explain various phenomena such as: differences in income between people and fields, the form of age-income curves, the relationship between age and income, and the effect of specialization on professional qualifications. G. Becker believes that for a long period of time "buman capital will be an important part of development programs, of income distribution, work results and many other issues."

T.O Davenport notes in his work, "Human Capital": "People have an innate set of abilities, behaviours and personal energy, and these elements make up the buman capital they use in their work. And they are the ones who own this capital, not their employers... Work is a bilateral exchange of value, not a unilateral exploitation of an asset by its holder." The 21 st century society values its employees in relation to what they know. Information is therefore the driving force behind the new economy.

Technological changes, increasing employer demands, the aging of the population, the education system and migration are the causes of the current labor market shortage. Workforce employment, especially young graduate employment, represents a structural indicator, allowing for a thorough analysis of the labour market structure and of the economic systems in terms of the balance between workforce supply and demand or in terms of the workforce employment quality. The increase in the young graduate employment rate is at the heart of many EU policies. 
Europe 2020 Workforce Employment Strategy encourages measures to help achieve three main goals by 2020, namely:

- Achieving a 75\% employment rate for people aged 20 to 64;

- Reducing early school drop-out rates below $10 \%$ and increasing the percentage of higher institution graduates to at least $40 \%$ among people aged between 30 and 34;

- Reducing by at least 20 million the number of people affected by poverty or by the risk of poverty and social exclusion. [7]

In June 2016, The European Commission adopted The New Skills Agenda for Europe []], under the heading "Working together to strengthen human capital, employability and competitiveness". The major goal is to ensure that people acquire the necessary present and future skills in order to increase employability, competitiveness and growth at the level of the whole European Union.

\section{Research methodology}

The research methodology involves analysing and interpreting the statistical data provided by specialized institutions on the European and national labour deficit. We have also tried to identify the causes that led to this situation and to estimate what their impact will be on the socioeconomic environment in the future. Thus, we took into account three key variables of this phenomenon, namely the phenomenon of migration, the aging population and education.

\section{The global situation}

The global situation does not differ much from the situation at a national level. It seems that the labour market shortage has been steadily increasing, starting with 2010, according to the following figure.

Figure no 1. Global talent shortages

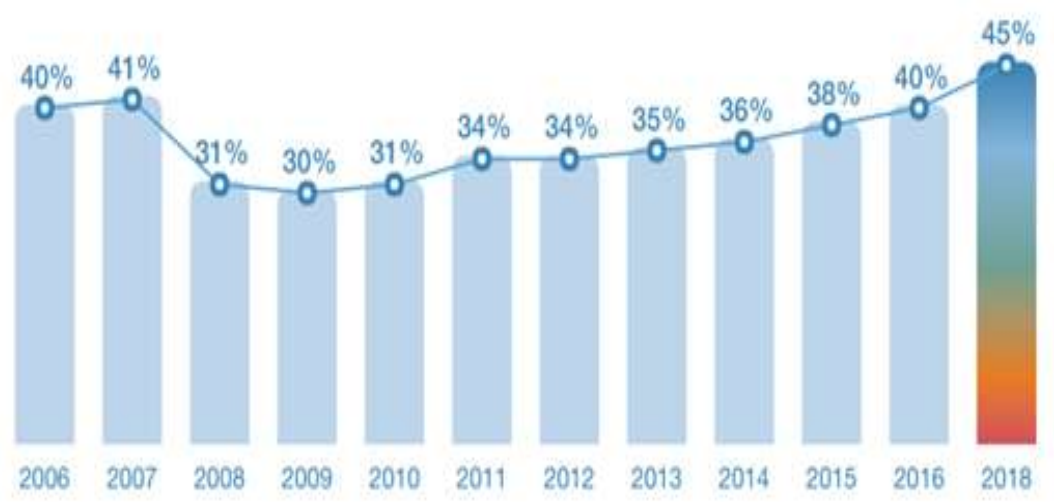

Source: Talent Shortage Survey 2018, ManpowerGroup

We may notice that, in 2018, Romania is alongside Japan and Taiwan among the top countries where employers find it difficult to find employees with job-specific skills. In Japan, this situation is justified both by the population aging phenomenon and by the high demand on the labour market. 
Tabel no 1. Countries and Territories Facing Difficulty Hiring in 2018

\begin{tabular}{|c|c|c|c|c|c|c|c|}
\hline \multicolumn{2}{|c|}{ Least Difficulty } & \multicolumn{2}{|c|}{$\begin{array}{ll}\text { Below } & \text { Average } \\
\text { Difficulty } & \end{array}$} & \multicolumn{2}{|c|}{$\begin{array}{ll}\text { Above } & \text { Average } \\
\text { Difficulty } & \end{array}$} & \multicolumn{2}{|l|}{ Most Dificulty } \\
\hline China & $13 \%$ & Australia & $34 \%$ & Finland & $45 \%$ & Argentina & $52 \%$ \\
\hline Ireland & $18 \%$ & $\Downarrow \quad$ Brazil & $34 \%$ & 1 Austria & $46 \%$ & † Slovakia & $54 \%$ \\
\hline UK & $19 \%$ & Belgium & $35 \%$ & USA & $46 \%$ & India & $56 \%$ \\
\hline Netherlands & $24 \%$ & Costa Rica & $35 \%$ & † Portugal & $46 \%$ & Singapore & $56 \%$ \\
\hline Spain & $24 \%$ & Panama & $35 \%$ & Israel & $49 \%$ & Greece & $61 \%$ \\
\hline Norway & $25 \%$ & Czech & $36 \%$ & † Mexico & $50 \%$ & Turkey & $66 \%$ \\
\hline France & $29 \%$ & Republic & $37 \%$ & Germany & $51 \%$ & Bulgaria & $68 \%$ \\
\hline South Africa & $32 \%$ & Italy & $38 \%$ & Hungary & $51 \%$ & Hong Kong & $76 \%$ \\
\hline \ Switzerlan & $33 \%$ & Guatemala & $40 \%$ & Poland & $51 \%$ & Taiwan & $78 \%$ \\
\hline d & & Slovenia & $41 \%$ & & & Romania & $81 \%$ \\
\hline & & Canada & $42 \%$ & & & Japan & $89 \%$ \\
\hline & & $\Downarrow$ Columbia & $42 \%$ & & & & \\
\hline & & Sweden & $43 \%$ & & & & \\
\hline & & Peru & $44 \%$ & & & & \\
\hline & & New Zeeland & & & & & \\
\hline
\end{tabular}

Source: Talent Shortage Survey 2018, Manpower Group

In the context in which the skills required for employment are in a permanent process of evolution, and the effects of the aging phenomenon are felt globally, there are also states where employers do not encounter hiring difficulties (China, Ireland, and U.K.).

\section{Labour shortage in Romania}

At present, the labour shortage is estimated at over 600,000 people, and this deficit is growing. In the beginning, those who brought foreign staff used this option because it represented cheaper workforce; those who brings it today do it because it is a stable workforce. The cost is no longer important but the stability of employees, especially at a time when the skilled labour force has migrated to Europe.

Under these circumstances, Romania has come to import labour force, especially since 4 million Romanians left the country. Migration analysis involves many perspectives. It is increasingly believed that migration is an essential and inevitable component of the economic and social life of each state, and that a migration that is under observation can be beneficial for both the individual and the society. In Romania, the numerous restructuring in the industry and the existence of a poor agriculture have led to an increase in the number of unemployed people and have led the people who lost their jobs to look for a job abroad.

In order to assess the temporary migration of some Romanians who are looking for jobs abroad, it is of an utmost importance to know the specific functioning mechanisms of the European Union, in which the free movement of labour force has been enacted. The labour market faces a significant labour shortage, especially in the construction and the hospitality industry, and the crisis of skilled workers has increased in the last year. Each year the Government sets a maximum number of new foreign workers from outside the European Union and the European Economic Area, who can work in our country. Currently this number is insufficient, assert the employers in the construction and the hospitality industry. The Government will also try to cover part of the labour shortage on the local market by importing non-EU workers in 2019. For the year 2019 a contingent of 13,500 new workers admitted to the labour market in Romania is proposed. Last 
year, the Government allowed employers to bring up to 15,000 new non-EU workers.[10] In 2017, most of the permanent foreign workers in our country were between 18 and 34 years of age. China, Turkey, the Philippines and Vietnam are the countries from which most of the extracommunity workers were brought to work in our country in 2017. During 2014-2016, the maximum number of new non-EU workers admitted to the labour market in Romania was 5,500 per year. But is the import of labour force a sustainable solution for the economic and social development of Romania? Perhaps we should analyse the causes of the emigration of almost 4 million Romanians, the high unemployment rate among the young population and the low degree of adaptation of the education system to the requirements of the labour market. We believe that the labour shortage in Romania has multiple and diverse causes. Further on, we shall analyse the implications of the education system on the current labour force shortage in Romania.

\section{Demographic aging}

Among the many global threats to humanity some demographic issues have often been mentioned. If several decades ago the primary demographic hazard was considered to be the extremely rapid demographic growth, today the main risk factor becomes one related to the population structure, namely the demographic aging process. The demographic aging of the population is the process of population age group structure change in favour of older age groups as a firm and long-lasting tendency. The factors which determined the demographic aging process may be direct (the decrease in birth rate, the influence of migration flows, the fertility rate reduction) or indirect factors (economic, political, social, cultural factors).

Figure no 2. Population structure by major age groups, EU-28, 2017-2080 (\% of total population)

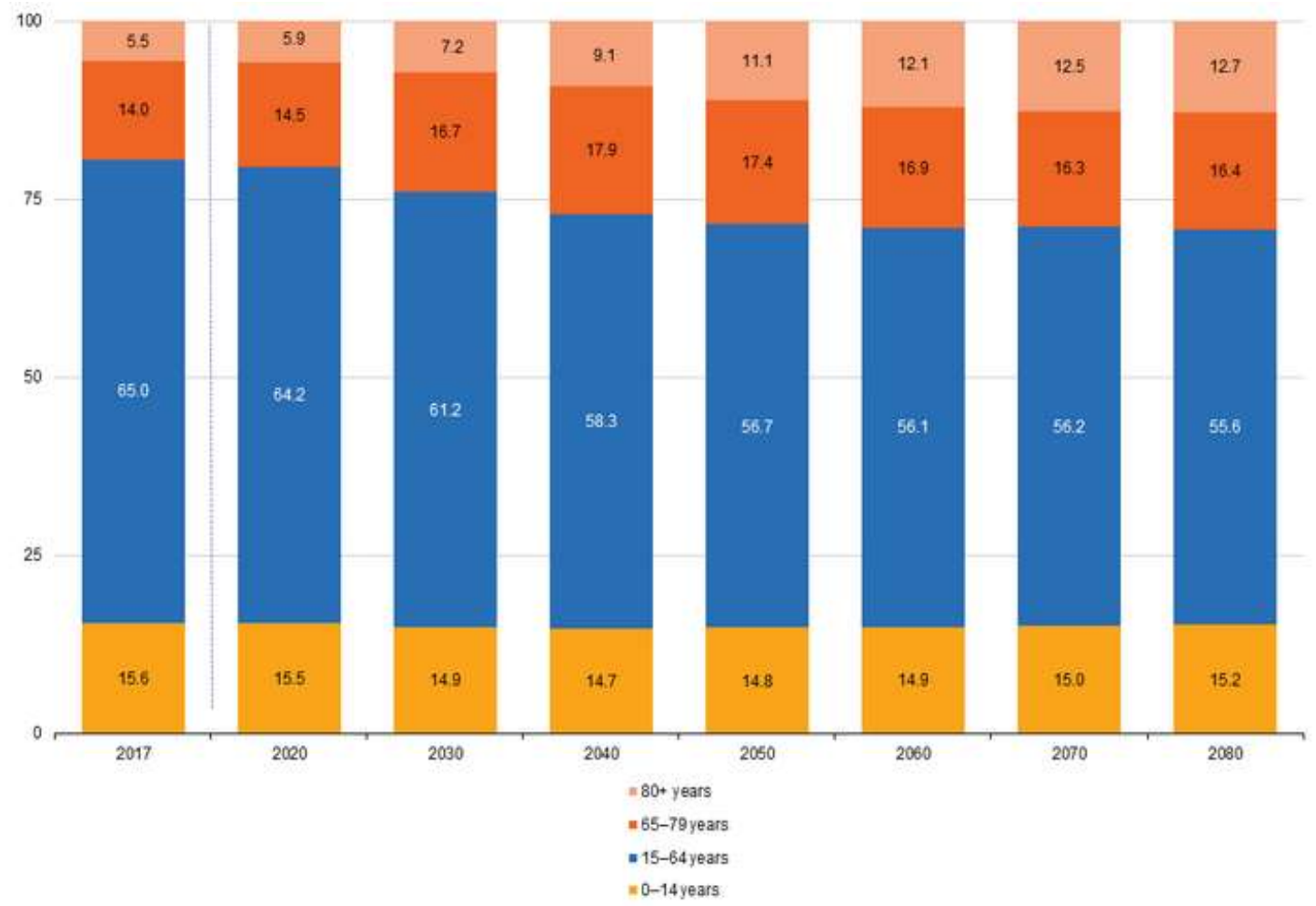

Source: https://ec.europa.eu/eurostat/statistics-explained, accessed at 10 January 2019 
The percentage of the population aged 65 and above is increasing in all EU Member States, in the EFTA countries and in candidate countries. The increase recorded in the last decade ranges from $4.9 \%$ in Malta and $4.4 \%$ in Finland to $1.4 \%$ in both Belgium and Germany and $0.1 \%$ in Luxembourg. Over the last decade (2007-17), there has been a global increase of $2.4 \%$ in the EU28. On the other hand, the percentage of the population being less than 15 years of age in EU-28 decreased by $0.2 \%$. (European Commission, 2018)

The aging trend of the population has a deep impact on all generations and on most of the economic and social activity areas: the labour market, social security, education, culture, politics. The demographic changes call into question the political institutions and strategies that were commissioned at a time when demographic prospects were significantly different. They also have an influence on the everyday life of the citizens, the relationship between generations and the way of life.

Population aging requires a complex political approach, including economic, employment and social issues. Companies must ensure not only the provision of an adequate framework for the elderly but also the economic and social viability in an aging world.

\section{Education systems implication of the on labor shortages}

The adaptation of Romanian higher education to the labour market developments and realities is an essential condition for ensuring both a competitive education process and the training of specialists who can find a job easier.

In the current socio-economic context, more and more young people have a job even as students. This fact is due to financial problems or the desire to earn extra income. Practice programs are an effective way to gain experience and to improve the personal curriculum vitae.

Most young people, once they leave school, start building a career. In one way or another, they all want important, well-paid jobs that offer as many benefits and bonuses as possible. Each of them seeks at least one source of motivation and a professional destination. Many of these fresh graduates want a job that will bring them material benefits first. The importance and attractiveness of such an internship is to acquire and develop applied professional skills such as teamwork or project management, the chance to gain real professional experience and, ultimately, to get a permanent job.

The experience gained during such an internship is very important, especially because nowadays the experience matters more than the many diplomas, certificates or courses you have attended. Most employers are looking for experienced people or, at least, willing to learn and accumulate as much information as possible in the shortest possible time.

In 2017 , the youth unemployment rate reached its highest level in Romania, 15.4\%, according to the data provided by the National Institute of Statistics (NIS), which coincided with a shortage of jobs on the labour market.

Young people aged 15-24 are severely affected by the consequences of the crisis, unemployment amongst this age group being a national and European concern. In many countries, the projections show a continued increase in the youth unemployment rate, especially in those countries where this indicator has so far been below the global average. 
Figure no 3. Youth unemployment rate in EU member states as of January 2018

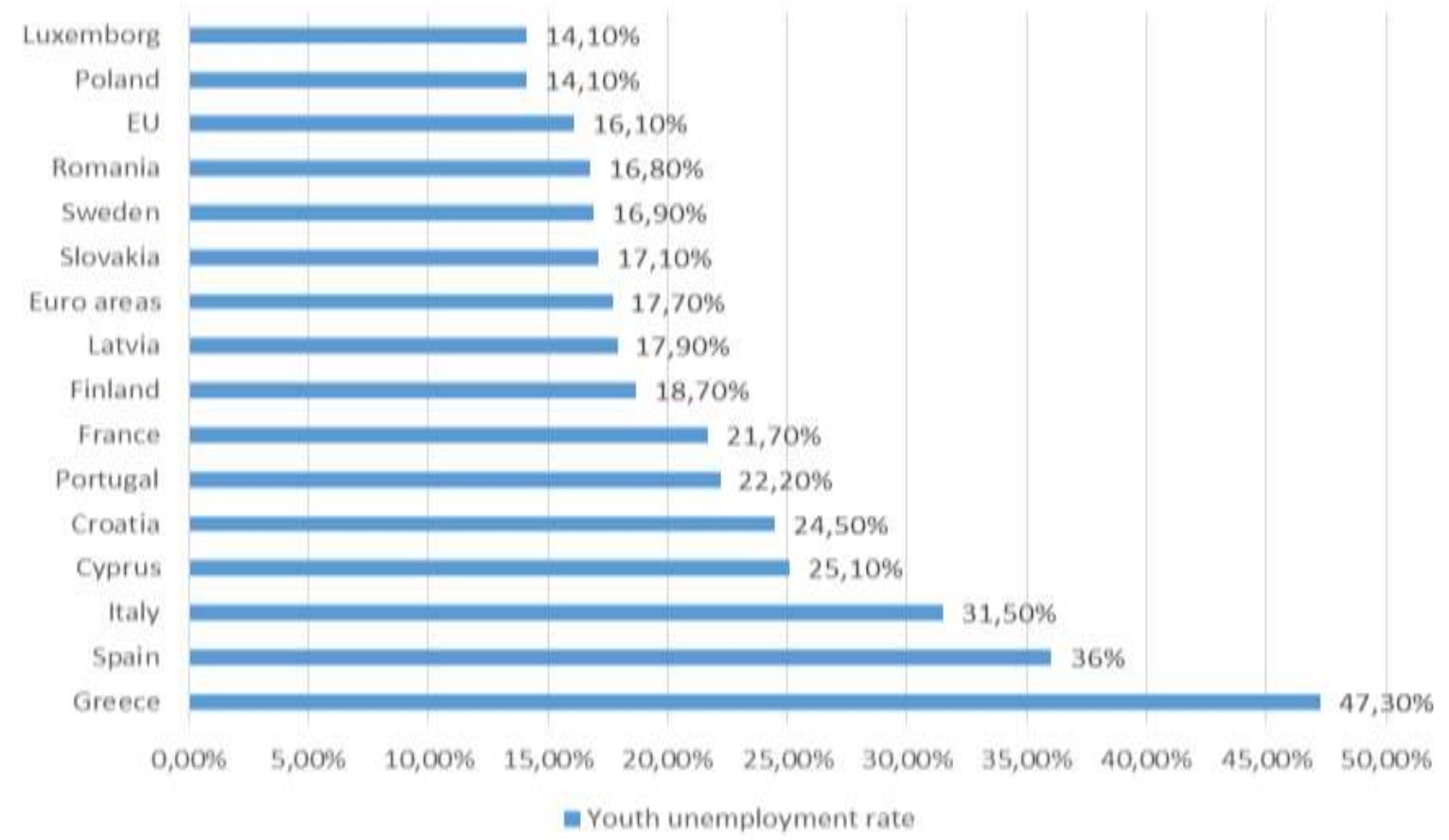

Source: https://www.statista.com/statistics/266228/youth-unemployment-rate-in-eu-countries/ Accessed at 20 December 2018

As we can see, most of the EU countries are faced with the difficulty of employment of young people, which is justified by the unemployment rate among them. The degree of accessibility on the labour market of young graduates is closely correlated with their level of skills and practical abilities.

The economic and social costs of youth unemployment represent important factors in lowering the potential for national economic growth [9]. The inadequacy of young people's skills to the demands of the labour market is becoming an increasingly obvious trend. This inadequacy makes solutions to the youth unemployment crisis require a much longer time to be implemented and to prove their effectiveness.

Structural changes underline the need to focus more on investing in human capital to support productivity growth. It is essential to develop policies at a European level that encourage the training, maintenance and use of human capital, to strengthen competitiveness and to support the European model of social welfare. Increasing the number of well-trained staff should be supported by the emergence of high quality jobs (Employment and Social Developments in Europe Review 2014). Reducing the pace of economic growth, together with an increase in unemployment, especially among young people, and long-term unemployment, may increase the risk of poverty and social exclusion within the EU population. (Workshop on 'Policy Areas and Current Challenges in the Field of Employment and Social Affairs at EU Level').

In this respect, universities are confronted with the constant need to build new skills, with the need to focus on educational processes and development strategies. Qualitative higher education, which is open to new ideas and adapted to labour market requirements, represents one of the most effective measures to reduce the risk of unemployment, social marginalization and exclusion among young people. At the same time, quality education is not only a fundamental aspect of the changes that take place in the life of each individual, but it is also a factor of the economic development of society.

Young people's pursuit of a competitive education process gives them the opportunity to adapt more easily to the labour market and to find those jobs adapted to the skills they have, whether they are specialized knowledge or skills. 
The penetration of young higher education graduates on the labour market is an important step in their life. Nowadays, the skills package obtained in the educational process, together with the aspirations and wishes of young graduates, are transformed into objectives. Also, the concrete challenges of finding a job, the success of the first steps in the career and the achievement of financial independence represent big steps in young people's lives.

Due to economic developments and the profound changes in the business environment and the technologies that surround us, this transition from school to the labour market has become increasingly complex for the current generation of graduates. Temporary or part-time jobs, returning to or continuing education are decisions and actions that young people today take more and more often.

\section{The effects of exporting labour force on the emigration countries}

Through its frequency and implications, international migration is an important explanatory element of the demographic and economic structures and dynamics. In their turn, the changes in the volume and functions of migration processes are determined mainly by economic circumstances, as well as by certain social needs. The subjective elements that occur at the time of the individual decision do not alter the intrinsic structure of the migration - objective and socially functional. That is why the enumeration of the reasons for migration remains an inconclusive operation as long as the complex interaction of economic, psycho-social, family, cultural, personal, ecological, situational variables is not revealed.

The effects on the economy vary from country to country, depending on the number of jobs for emigrants, on the structure of the country's emigration economy, and on the effectiveness of the government's economic policy in organizing and controlling the use of labour and on remuneration.

Migration is influenced by a combination of economic, political, social and environmental factors: either in the country of origin of a migrant (impulse factors) or in the country of destination (attraction factors). From a historical point of view, it is considered that the relative economic prosperity and the political stability in the EU have led to a considerable attraction effect on immigrants.

In the destination countries, international migration can be a tool used to address specific labour market deficits. However, it is almost certain that migration, considered individually, will not be able to reverse the current aging trend of the population registered in many areas of the EU.

From a financial point of view, there are considerable losses to countries that funded investment in the training of the emigrated workforce. Practically, these losses consist of the education costs and, therefore, the lack of contribution for own development of highly qualified staff.

\section{Conclusions}

Both on a global and on a national level there is a reorientation of economic strategies, especially those aimed at the labour market, in order to increase the insertion of young people into the labour market and the correlation of the education system with the current requirements related to the required competencies by employers. Achieving this goal will have three important consequences: reducing the unemployment rate, decreasing poverty by reducing the inequality of income and providing the resources needed by a society to protect its disadvantaged segments.

We must be aware that the labour force factor has become part of the development equation, not only due to the quantitative side, but also due to the qualitative-structural one, and that it becomes the bearer and symbol of power of a nation - an attribute that evolves almost quasiexponentially today due to intellectual power.

\section{References}


[2] Armstrong M., Managementul resurselor umane, Editura Codecs, Bucuresti, 2003, p. 49

[3]Becker G., Comportamentul uman o abordare economică, Editura All, Bucureşti, 1994, p. 137

[4]Davenport T.O., Human Capital, Jossey Bass, San Francisco, 2004

[5]Duta, A.; Iannelli, C. Social Class Inequalities in Graduates' Labour Market Outcomes: The Role of Spatial Job Opportunities. Soc. Sci. 2018, 7, 201.

[6]Eurofound and International Labour Organization (2019), Working conditions in a global perspective, Publications Office of the European Union, Luxembourg, and International Labour Organization, Geneva.

[7]European Commision, Labour market and Labour force survey (LFS) statistics, European Commission, Youth unemployment rate in EU countries, 2018, https:// wnwn.statista.com/statistics/266228/youth-unemployment-rate-in-eucountries/

[8] European Commission adopted The New Skills Agenda for Europe [COM (2016) 381/2]

[9]Gazier B., Economie du travail et de l'emploi, Editura Dalloz, 1991, p.193

Giarini O., Liedtke P., Dilema ocupării forței de muncă și viitorul muncii, Editura All Beck, Bucureşsti, 2001, p. $32-35$

[10]Manpower Group, Talent Shortage Survey 2018, https:/ / insights.manpowergroupsolutions.com/2018-talent-shortagesurvey/

[11]Novo-Corti, I.; Tîrcă, D.-M.; Ziolo, M.; Picatoste, X. Social Effects of Economic Crisis: Risk of Exclusion. An Overview of the European Context. Sustainability 2019, 11, 336. 